\title{
DECREASE OF BUILDING'S HUMIDITY WITH EPIPHYTE AND XEROPHYTE
}

\section{Erlina Laksmiani Wahjutami}

Antariksa

Agung Murti Nugroho
Post graduate student of Environmental Science, Brawijaya University, Malang, Indonesia e-mail: erlina.laksmiani@unmer.ac.id

Lecturer of Architecture Department, Brawijata University, Malang, Indonesia

Lecturer of Architecture Department, Brawijaya University, Malang, Indonesia

Lecturer of Biology Department, Brawijaya University, Malang, Indonesia

Received: September $1^{\text {st }}$ 2015; Accepted: September $14^{\text {th }}$ 2015; Available Online: December $31^{\text {st }} 2015$ DOI: http://dx.doi.org/10.18860/jia.v3i4.3091

\begin{abstract}
This article is part of the research phase in Environmental Sciences Doctoral study program that is interdisciplinary research, ongoing. Architecture disciplines collaborate with the disciplines of biology to solve the problem of the microclimate in the built. Paradigm used as benchmarks is bioclimatic architecture in which there is a relationship between elements of the building, climate, and living organisms. Living organisms - in this case the plant - used as a tool to solve the problem of the microclimate in buildings. Plant is one of the living organisms that grow and thrive in their respective habitats and the climate of each character. Several studies have shown that plants are able to lower both ambient temperature and the temperature inside the building. In this study, the problem is the existence of a higher humidity levels in small type of dwelling (STD) that has been totally renovated. Meanwhile Epiphytic and Xerophyte are plants that live by absorbing surrounding moisture. In the next stage of research, it is expected that the capability of Epiphyte and Xerophyte's plants to reduce the building's humidity proven. From the interpretation Q.S. 23: 17, implied that: Allah has bring down the water to the earth to grow a variety of plants [1]. The diversity of these plants would be useful for people who have sense. Building as the built environment will become sustainable environment when the human capable of utilizing plants as part of it.
\end{abstract}

Keywords: Small type dwelling (STD), building's humidity, Epiphyte's plant , Xerophyte's plant

\section{Introduction}

This research is the doctoral study program in environmental science as interdisciplinary research. In this study the science of architecture in collaboration with the science of plant biology. There are several stages of the implementation of the research as a method to prove the hypothesis. The research hypothesis is that the humidity of the building can be reduced by the placement of Epiphyte and Xerophyte's plants in the building.

The idea of such research comes from a concern of researchers to the problems that arise in the STD in Malang, Indonesia. The totally renovated of the
STD usually has problems in the lighting system and its air circulation. The lack of light intensity and the wind flows into the building cause the building's humidity rising.

\section{Hot-humid climate}

Indonesia is tropical humid regions with the character of the climate where temperatures in nearly the same throughout the year, having high relative humidity that can reach up to $90 \%$ and more [2]. Such type of climate showing that there are almost no significant differences between rainy and dry season. The average temperature between 22- 
$23^{\circ} \mathrm{C}$, with the relative humidity varied from $60 \%$ in the daytime and approaching $95 \%$ at night and in the morning [3]. On such type of climates, the requirement for building's convenience will be fulfilled when there is an optimization of cross ventilation system, natural lighting, rooms's temperature and low relative humidity [4],[5]. According to [6], the relative humidity below $30 \%$ or above $70 \%$, the humans start feeling inconvenience.

The high humidity brings a significant impact on humans and buildings. Mold growth in buildings can affect a detrimental effect on the health of the occupants [7]. Humidity in residences also will damage the coating and frame building [8].

\section{Bioclimatic Architecture}

Basically, the concept of bioclimatic architecture focuses on three main points, namely: the relationship between living organisms and climate; form; and the building 's structure [9]. The building is no longer just an artificial environment that stands alone in its environment. A building should really consider climate character of its surroundings. This will affect the design of the shape and structure of the building. The role of living organisms, i.e. plants, must be taken into account in the design and is expected to improve the microclimate in the building.

\section{The Role of Plants in Improving Thermal Comfort}

Several studies demonstrate the role of plants in improving the micro-climate inside the building include: plants help remove air pollutants [10]. Hedera helix as vines influence the micro-climate (temperature and relative humidity) on the wall of the building [11]. Garden plants through vertical or horizontal configuration, enabling an increase in air quality, the increase biodiversity and reduce heating and refreshing region, in addition also has aesthetic value [12]. Vegetables are able to lower the room's temperature and produce oxygen as arrange in the form of a vertical garden [13].

Other researches focused on the green roof. Green roof is as an passive cooling in the building [14]. The green roofs thermally performance in tropical climates in high-rise buildings with density will beautify the environment and improving the Singapore's image as the garden city; improving air quality; creating better thermally conditions and mitigation thermal urban heat island; providing amenity space for residents; adding identity and improving the attractiveness of the building beauty [15]. Economic benefits of green roofs [16].

The next one is other studies which applying vertical garden system. First experimental discusses the impact of vertical garden system in reduce the temperature of the surface of a building in tropical climates, leading to the reduction of the burden of cooling and cost of energy [17]. The plant's effects of thermal on the performance of a vertically greening system[18]. The use of the horizontally and vertically greening have an important effects on performance of building's thermal and influence urban environment too, both in summer and winter. Plant serves as a filter the sun and prevent radiation of heat adsorption building material broad [19].

Some research from above, it concludes that the role of plants in restoring the micro climate is significant. Back to the beginning of basic subjects of where humidity becomes the main problem, on this research, bioclimatic approach through plants become main focus. The predicted plants capable of absorbing humidity is of a kind of epiphytic plants and xerophytes.

\section{Epiphyte and Xerophyte as Humidity Absorber Plant}

Epiphyte is a plant that grows in many tropical rainforest. These plants have no roots in the soil as plants in general. It grows attached to the top of the tree that serves as its host plant, but is not parasitic or harmful. For the growth of the plant, it absorb humidity and nutrients from the surrounding air and rain [20].

Xerophyte is a plant that grows in hot dry climate. Both of these plants have a high resistance to drought.

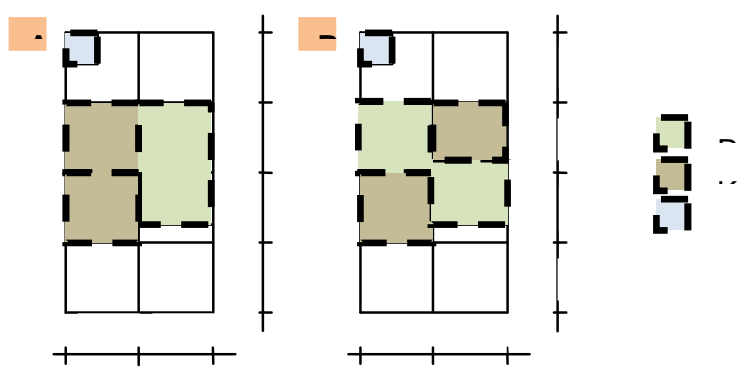

Figure 1. Criteria STD based on Minester's Decree Source : Private documentation

184 | Journal of Islamic Architecture Volume 3 Issue 4 December 2015 • ISSN 2086-2636 • e-ISSN 2356-4644 


\section{Criteria of Small Type Dwelling}

The criteria for small type residential is based on the Decree of the Minister of Settlement and Regional Infrastructure No. 403/ kpts/m/200 Technical Guidelines on Simple Healthy House. Such criteria for the category of small-type residences is where the buildings area between 27-36 $\mathrm{m}^{2}$ with total area of effective between $72-90 \mathrm{~m}^{2}$ (Figure 1).

\section{Materials and Methods}

In the preliminary research, collecting data of the totally renovated STD done in Malang, Indonesia. Floor plans, elevations and section drawn to indicate the position of lighting and its air circulation. Furthermore, the temperature and humidity are measured using HOBO RH and temperature sensor. Measurements were taken at the peak of the rainy season and the dry season. This step is to ensure that the totally renovated STD with a lighting system and air circulation unfavorable will lead to high levels of humidity.

The next phase of research is collecting data of plants that absorb humidity that is required process of photosynthesis. Epiphyte and Xerophyte are plants in accordance to this criteria. Epiphyte species selected are Platycerium bifurcatum (Staghorn fern) and Asplenium nidus (Bird's nest), while from Xerophyte species selected are Aloe vera and Sansevieria trifasciata (Snake Plant). The fourth of these plants then observed its morphology (Figure 2).
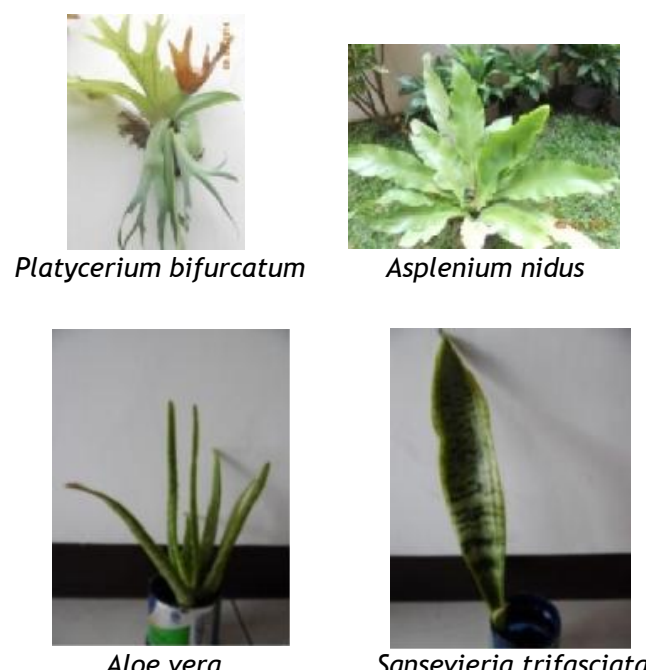

Figure 2. Epiphyite dan Xerophyte researched Source : Private documentation

\section{Results}

One of the observation results of totally renovated STD is shown in the figure below (Figure $3)$. From the description of floor plans, elevations and section, it appears that the opening of the building to get the lighting and air circulation naturally on the front section. While the position of the openings in the back do not get sunlight and air flow directly. It can be predicted that the humidity will be high in the rear area.
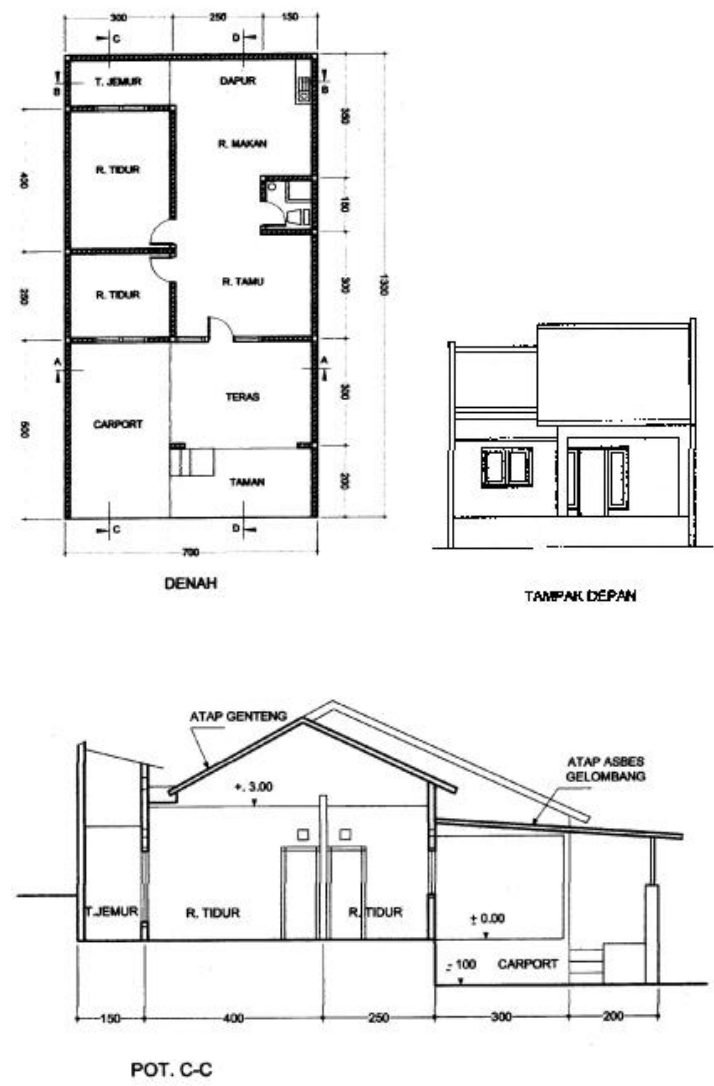

Fig 3. Totally renovated STD Source : Private documentation

The results obtained of the temperature and humidity measurements in dry season, the data found that the average temperature reaches 25 $28^{\circ} \mathrm{C}$, while the humidity average shows the figures above $70 \%$. Based on table 1, the average combination of temperature and humidity indicates of thermal discomfort in the building. 
Table 1: The influence of temperature and humidity to the comfort of the room Source: Gut, Ackerknecht in (5)

\begin{tabular}{ccc}
\hline $\begin{array}{c}\text { Relative } \\
\text { humidity }\end{array}$ & $\begin{array}{c}\text { Comfortable } \\
\text { temperatures } \\
\text { during the day }\end{array}$ & $\begin{array}{c}\text { Comfortable } \\
\text { temperatures } \\
\text { at night }\end{array}$ \\
\hline $0-30 \%$ & $22-30^{\circ} \mathrm{C}$ & $20-27^{\circ} \mathrm{C}$ \\
$30-50 \%$ & $22-29^{\circ} \mathrm{C}$ & $20-26^{\circ} \mathrm{C}$ \\
$50-70 \%$ & $22-28^{\circ} \mathrm{C}$ & $20-26^{\circ} \mathrm{C}$ \\
$70-100 \%$ & $22-27^{\circ} \mathrm{C}$ & $20-25^{\circ} \mathrm{C}$ \\
\hline
\end{tabular}

Table 2 shows a comparison of roots, stems and leaves of the plants observed.

Table 2. Comparisons of roots, stems, leaves and other specific characters

Sources : Private documentation

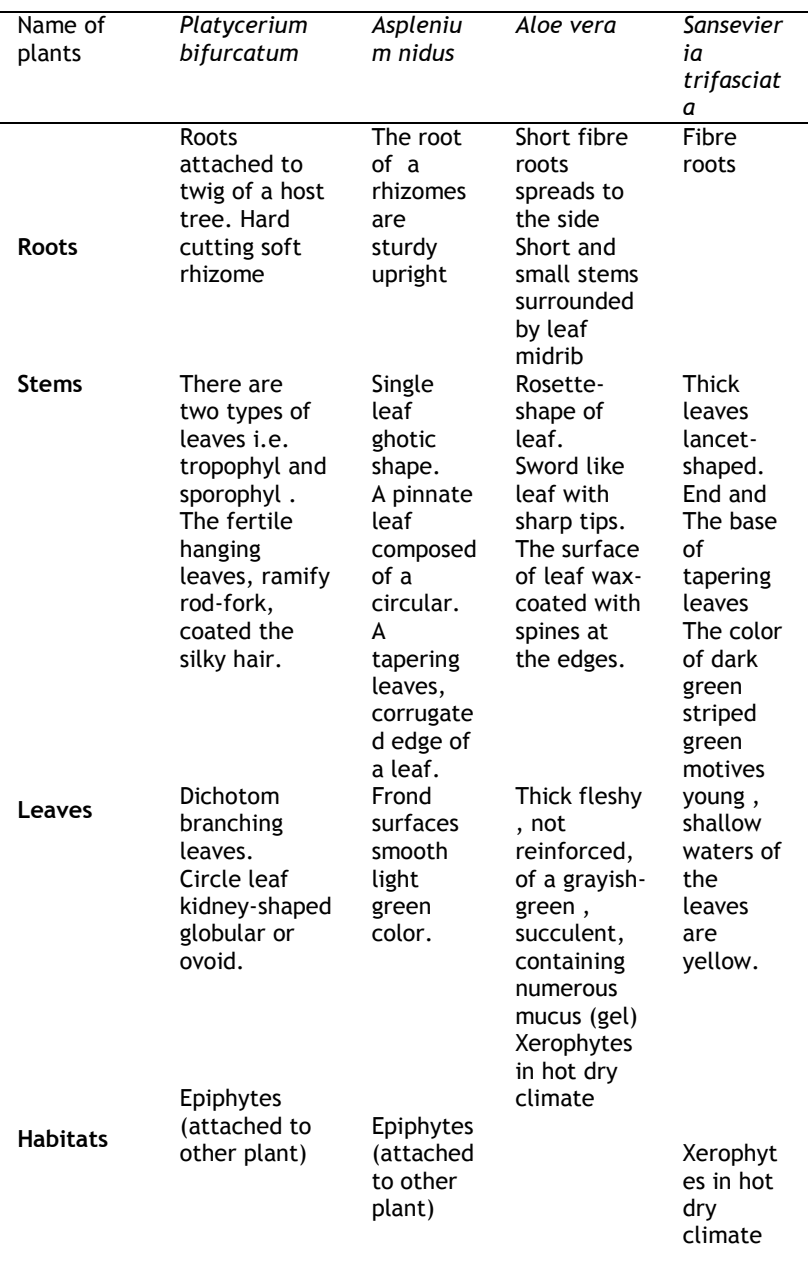

The results of this preliminary observations will lead early on the alleged that the types of plant is able to to absorb humidity in the surrounding environment.

\section{Discussion}

From the observation of morphology of roots, Platycerium bifurcatum have strong roots attached to the former host tree, Asplenium nidus its root fibers strongly attach to the growing media. Both plants together to form a bowl that is useful to absorb humidity and rain water as well as the media to gather useful nutrient for plant growth and development. Aloe vera plant roots and Sansevieria trifasciata shallow and close to the soil surface. This is to facilitate and accelerate the absorption of humidity or rain.

The results of the observation of stems morphology, either Platycerium bifurcatum, Asplenium nidus, Aloe vera, or Sansevieria trifasciata have stems that is barely not visible. Platycerium bifurcatum and Asplenium nidus have short and resilient stems. The stems of Aloe vera and Sansevieria trifasciata are succulent. This is a selfdefense mechanism against drought.

From the observation of morphology of leaves, Platycerium bifurcatum has a leaf surface -covered by smooth and thick fur. This prevents water easily evaporates. It has two types of leaves: tropopfil to photosynthesize, and sporofil which will produce spores for genetic breeding. Tropofil leaves will dry up in the dry season and replenishes nutrients for plants. Asplenium nidus, the leaves are smooth and ductile reinforced by leaf bones strong. The leaves of Aloe vera and Sansevieria trifasciata have a thick layer of wax to prevent evaporation. The leaves are also succulent that shows the efficiency of water storage. The water reserves will be utilized in the even of drought.

\section{Conclusion}

In the hot and humid tropical region, where the lighting system and its natural air circulation is less, is predicted to be an increase in temperature and humidity in the building. Temperature and humidity measurement results on STD space in accordance with the criteria as mention previously. It clearly shows the temperature and humidity levels are high.

186 | Journal of Islamic Architecture Volume 3 Issue 4 December 2015 • ISSN 2086-2636 • e-ISSN 2356-4644 
When the plants grows in the higher part of trees, away from the ground, makes the morphology of epiphytic plants adapt to its living, in particular to meet the water needs in the process of photosynthesis. Bowl shape or nest serves as a water and nutrients trap that plants need.

In the dry hot climatic, where water is very difficult to find, Xerophyte catch droplets of humidity in the surrounding air. Alleged that apart from morphological traits that show efficiency in water storage, there are other mechanisms in the body that causes the plants able to survive in such extreme climatic conditions.

For further research on plants, it is required to do research on the anatomy, position and density of stomata each plant. This relates to the stomata function as an organ of respiration, the exit and entry of $\mathrm{O}_{2}, \mathrm{CO}_{2}$ and $\mathrm{H}_{2} \mathrm{O}$ in the process of photosynthesis, respiration and transpiration. From the observation of stomata to be, it is expected to strengthen the notion of Epiphyte and Xerophyte ability to absorb humidity.

The final results expected from this research, Epiphytic and Xerophyte can reduce indoor humidity in STD.

\section{Acknowledgment}

We would like to thank to the Ministry of Education and Culture which has provided scholarships BPDN for the implementation of the doctoral program of study Environmental Science.

\section{References}

[1] “No Title." [Online]. Available: http: / /atafsirquran. blogspot.co.id/2013/04/ tafsir-az-zumar-ayat-21-31.html. [Accessed: 03-Sep-2015].

[2] G. Lippsmeier, Tropenbau Building in The Tropics. [trans.] Syahmir Nasution. Munchen : s.n., 1980.

[3] N. H. Feriadi, Henry and Wong, "Thermal comfort for naturally ventilated houses in Indonesia.," Build. Environ., vol. Vol. 36, pp. pp. 614-626, 2004.

[4] C. E. Mediastika, Hemat Energi dan Lestari Lingkungan Melalui Bangunan. Yogyakarta: Andi Offset, 2013.

[5] T. H. Karyono, Green Architecture:
Pengantar pemahaman arsitektur hijau di Indonesia, 1st ed. Jakarta: Rajawali Pers, 2010.

[6] A. Frick, Heinz, Ardiyanto, Antonius and Darmawan, Ilmu Fisika Bangunan. Pengantar pemahaman cahaya, kalor, kelembaban, iklim, gempa bumi, bunyi, dan kebakaran. Yogyakarta: Kanisius, 2008.

[7] J. A. Clarke, "A technique for the prediction of the conditions leading to mould growth in buildings," Build. Environ., vol. Vol. 34, pp. pp. 515-521., 1999.

[8] et al Lucas, Franck, "Study of moisture in buldings for hot humid climates," Energy Build., vol. Vol. 40, pp. pp. 345-355, 2002.

[9] R. Hyde, Bioclimatic Housing. Innovative Designs for Warm Climates. London: Earthscan, 2008.

[10] et al Fujii, Shuji, "Effects on air pollutant removal by plant absorption and adsorption," Build. Environ., vol. Vol. 40, pp. pp. 105112, 2005.

[11] A. Sternberg, Troy, Viles, Heather and Cathersides, "Evaluating the role of ivy (Hedera helix) in moderating wall surface microclimates and contributing to the bioprotection of historic buildings," Build. Environ., vol. Vol. 46, pp. pp. 293-297, 2011.

[12] A. Perini, Katia and Magliocco, "The integration of vegetation in architecture, vertical and horizontal greened surfaces," Int. J. Biol., vol. Vol. 4, pp. pp. 79-91, 2012.

[13] A. M. Santoso, Eddy Imam, Ariffin and Nugroho, "The effect of vegetable garden on the roof building due to the indoor thermal comfortability," J. Basic Appl. Sci. Res., vol. Vol. 3, pp. pp. 941-950, 2013.

[14] T. G. Theodosiou, "Summer period analysis of the performance of a planted roof as a passive cooling technique," Energy Build., vol. Vol. 45, pp. pp. 18-22, 2003.

[15] C. Hien, Wong Nyuk, Yok, Tan Puay and Yu, "Study of thermal performance of extensive rooftop greenery systems in the tropical climate," Build. Environ., vol. Vol. 42, pp. pp. 25-54, 2007.

[16] et al Wong, Nyuk Hien, "Life cycle cost analysis of rooftop gardens in Singapore," Build. Environ., vol. Vol. 38, pp. pp. 499509, 2003.

[17] et al Wong, Nyuk Hien, “Thermal evaluation 
of vertical greenery systems for building walls," Build. Environ., vol. Vol. 45, pp. pp. 663-672, 2010.

[18] L. . Cheng, C.Y., Cheung, Ken K.S. and Chu, "Thermal performance of a vegetated cladding on facade walls," Build. Environ., vol. Vol. 45, pp. pp. 1779-1787, 2010.
[19] K. et al,Perini, "Vertical greening systems and the effect on air flow and temperature on the building envelope," Build. Environ., vol. Vol. 46, pp. pp. 2287-2294, 2011.

[20]

"No." [Online]. Available: http://www.digplanet.com/wiki/Epiphyte . [Accessed: 14-Aug-2015]. 